\section{New APSA Council Members Elected}

$\mathrm{E}$ ight new members of the APSA Council have been elected in APSA's fifth contested election in recent years. The new council members are: Cristina Beltrán, Haverford College; Yun-han Chu, Academia Sinica/National Taiwan University; Mark A. Graber, University of Maryland; Evelyne Huber, University of North Carolina, Chapel Hill; Thomas E. Mann, Brookings Institution; Joseph P. McCormick II, Pennsylvania State University, York; Julie Novkov, State University of New York, Albany; and S. Laurel Weldon, Purdue University. Mark Blasius was not elected.

Total voter turnout for the election was 4,211 , which is $32.0 \%$ of all eligible voters. In the past, the association has had 30.3, 30.4 , and $30.8 \%$ voter turnouts for the election. Catherine Zuckert, University of Notre Dame; John Ishiyama, University of North Texas; and Dan Reiter, Emory University, comprised the Elections Committee that certified the results. The vote was conducted by Campus-Vote.com under contract to APSA.

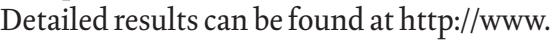
apsanet.org/content_66548.cfm.

Under APSA election rules, the Nominating Committee proposes one name per open seat and additional nominations, sponsored by at least 10 members, may be made from the membership. This year, Julie Novkov was nominated from the membership and was elected. The new council members take office immediately.

\section{Small Research Grant Competition}

T The APSA Small Research Grant Program supports research in all fields of political science. The intent of these grants is to support the research of political scientists who are not employed at Ph.D.-granting departments in the field and to help further the careers of these scholars.

Grant recipients have been able to publish several books and book chapters, journal articles, working papers, and conference pre- sentations. A small number of these grants are awarded annually by the APSA Council on the basis of a peer-review process. Individual grants do not exceed $\$ 2,500$ and are not renewable. Application are due by February 1, 2010. Visit www.apsanet.org/content_9222.cfm for eligibility requirements and more information.

\section{MFP Announces New Class}

\author{
PSA's Minority Fellowship Pro- \\ A \\ gram has named the 2010-11 fel- \\ lows. They are: \\ Edgar Alfonesca, Binghamton University \\ Jesse James Atencio, Washington \\ University in St. Louis
}

Parris Baker, University of Florida

Lashonda Brenson, University of Rochester

Chinbo Chong, University of California, Berkeley

Jenny V. Gallegos, Boise State University

LaGina Gause, Howard University

Victoria Marie Jackson, Pennsylvania

State University

David Lopez, University of Florida

Maisha Rashid, Barnard College

Camillia A. Redding, Rochester University

Robert William Velez, Metropolitan State University

The Program Selection Committee was comprised of Dr. Ben Marquez, Committee on the Status of Latinos and Latinas in the Profession; Dr. Alice Jackson, Committee on the Status of Blacks in the Profession; and Dr. Ann Chih Lin, Committee on Asian Pacific Americans in Political Science, chair.

Since 1969, the APSA Minority Fellowship has designated more than 500 fellows, both funded and unfunded, and contributed to the completion of doctoral political science programs for over 100 individuals. The association has refocused and increased efforts to assist minority students in completing their doctorates by concentrating not only on minority recruitment, but also assisting with the retention of these groups within the profession.

The APSA Minority Fellows Program designates up to 12 stipend minority fellows each year. Additional applicants who do not receive funds from the association may also be recognized and recommended for admission and financial support to graduate political science programs. Fellows with stipends receive a $\$ 4,000$ fellowship that is disbursed in two $\$ 2$,ooo payments-one at the end of their first graduate year and one at the end of their second-provided that they remain in good academic standing. Awards are based on students' undergraduate course work, GPA, extracurricular activities, GRE scores, and recommendations from faculty.

\section{AAUP Launches Action Campaign to Protect Academic Freedom}

Th $\mathrm{n}$ the face of threats to academic freedom at public colleges and universities, the American Association of University Professors has launched an awareness and action campaign called "Speak Up, Speak Out: Protect the Faculty Voice." The foundation of the project is a comprehensive report (available at http://www. aaup.org/AAUP/comm/rep/A/postgarcettireport.htm) from a subcommittee of the AAUP's Committee A on Academic Freedom and Tenure that examines the 2006 U.S. Supreme Court decision in Garcetti v. Ceballos and its aftermath. The Court found that government can restrict the speech of public employees when they comment on issues related to their "official duties." While the decision specifically set aside "speech related to scholarship or teaching," recognizing that such speech might have greater constitutional protection, several lower courts have ruled recently that faculty members who speak out on matters affecting their institutions are not protected under the First Amendment.

The report provides an analysis of these decisions and their implications for academic freedom, and recommends a number of action steps, including adoption of specific policy language designed to ensure the continued protection of academic freedom and shared governance. To supplement the report, AAUP has developed an online toolkit, available at http://www.aaup.org/AAUP/ 
protectvoice/overview.htm. Materials include an action plan, proposed policy language, opinion columns, and other materials that may be used by general-interest and campus publications, education journals, and Web sites supporting the cause of free speech at public colleges and universities.

\section{Tulane University Censure Removal}

\begin{abstract}
A series of favorable developments at Tulane University led the American Association of University Professors at its 2009 annual meeting to delegate authority to Committee A on Academic Freedom and Tenure to remove Tulane University's censure once the Tulane administration provided assurance that it would not cite the removal as a factor in any litigation. Having received a response that it deemed suitable, the committee at its fall meeting acted to lift the Tulane University censure.

Tulane was one of five institutions investigated by the Association's Special Committee on Hurricane Katrina and New Orleans universities. Of the five, the Louisiana State University Health Sciences Center was not placed on censure, and censure in the case of Southern University New Orleans was removed in 2008. With the 2009 removal of Tulane University, remaining on censure are the University of New Orleans and Loyola University New Orleans.
\end{abstract}

\section{Organized Section Awards Update}

T he October 2009 issue of PS listed the award recipients for APSA's Organized Sections. Since then, more awardees have been named.

Section 6: Public Administration 2009 Herbert Simon Book Award: Norma Riccucci, How Management Matters: Street-Level Bureaucrats and Welfare Reform (Georgetown University Press, 2005).

Section 19: International Security and Arms Control

Kenneth Waltz Dissertation Prize:

Vaidyanatha Gundlupet-Venkataramu, University of Chicago, supervised by

John Mearsheimer, "Big Sticks and

Contested Carrots: A Power-Centric
Theory of International Security."

Section 24: Politics and History

J. David Greenstone Award Committee

(Book):

Karen Barkey, Columbia University, Empire of Difference: The Ottomans in Comparative Perspective (Cambridge, 2008)

Mary Parker Follett Award Committee (Article):

Alan Jacobs, British Columbia, “The Politics of When: Redistribution, Investment and Policy Making for the LongTerm," British Journal of Political Science Walter Dean Burnham Dissertation Award:

Iza Hussin, University of Massachusetts, Amherst, "The Politics of Islamic Law: Local Elites, Colonial Authority and the Making of Islamic Law"

Section 30: Politics, Literature, and Film

Sabeel Rahman and Sheena Chestnut, "The Literary Public Sphere in PostAuthoritarian Transitions: Gao Xingjian, Orhan Pamuk, and J. M. Coetzee"

Section 31: Foreign Policy

Best Paper:

Peter Trubowitz and Jungkun Seo, "Partisan Ambition and Scapegoat Theory: U.S.-China Relations in Political Perspective."

\section{Call for Proposals to Add Questions to the 2012 GSS}

The General Social Survey invites scholars to submit proposals to add questions to its 2012 survey. Proposals will be accepted on the basis of scientific quality and scholarly interest. Outside funding is not necessary.

The General Social Survey (GSS) project expects to include some user-designed, project-funded items or topical modules when it collects data in its 2012 survey, and invites proposals for such items or modules from users. Proposals submitted in response to this call need not be accompanied by funding to support costs of data collection and data processing. They will be judged with their scientific merit as a primary consideration. Significant lead time is required before new material can be included on a GSS survey. To be considered for inclusion in the 2012 GSS, investigators should submit proposals to Tom W. Smith, the principal investigator and director of the GSS at
NORC (smitht@norc.uchicago.edu; phone 773-256-6288) no later than April 2, 2010. To view the proposal guidelines, visit http:// www.norc.org/GSS+Website/.

The GSS is a nationally representative survey of non-institutionalized adults in the United States, conducted primarily via face-to-face interviews. A National Science Foundation (NSF) grant provides foundational support for the GSS, and for inclusion of items submitted in response to this call; other sources provide supplementary support, typically for the inclusion of topical modules. GSS data are collected every two years, and made available to the research community and the public as soon as possible after data collection is complete.

\section{American Politics Research Call for Papers on Interest Group Politics}

1 merican Politics Research announces a call for papers for a special issue on interest group politics in the United States to be published early in 2011. Suitable topics might include studies of interest group influence on the bureaucracy, the presidency, the U.S. Congress, the courts, the political parties, and the policy process more generally. Research on interest group giving to campaigns, studies of interest group strength and organization, and papers on interest group networks would be welcome. Other possible topics include studies of interest group activity at the state and local level; interest group framing of issues; the nature of lobbying activity; group formation; the analytic and political utility of interest group scores; and group access to decision makers. Studies of specific groups or large subsets of the interest group community are invited, including social movement groups, as well as traditional economic groups and PACs.

The deadline for submission of papers is May 15, 2010, although articles will be accepted and reviewed before then on a rolling basis. All papers should be approximately 20-25 pages in length (see http://www.bsos. umd.edu/gvpt/apr/ for submission guidelines). Questions, as well as electronic submissions, should be directed to Jim Gimpel, editor, at apr@gvpt.umd.edu. 